INFO ARTIKEL

Riwayat Artikel:

Diterima : 15 Desember 2018

Disetujui : : 10 Januari 2019

\title{
PENDIDIKAN
}

\section{EVALUASI PELAKSANAAN STANDAR PROSES PEMBELAJARAN KKNI PROGRAM STUDI PENDIDIKAN GEOGRAFI UNIVERSITAS PGRI PALEMBANG}

\author{
Susanti Faipri Selegi \\ Pendidikan Geografi Universitas PGRI Palembang \\ $(\bowtie)$ susantifaipriselegi@gmail.com
}

\begin{abstract}
ABSTRAK
Kerangka Kualifikasi Nasional Indonesia (KKNI) merupakan kerangka penjenjangan kualifikasi kompetensi yang menyandingkan, menyetarakan, dan mengintegrasikan antara bidang pendidikan dan bidang pelatihan kerja serta pengalaman kerja dalam rangka pemberian pengakuan kompetensi kerja sesuai dengan struktur pekerjaan di berbagai sektor. Pelaksanaan kurikulum KKNI di Program Studi Pendidikan Geografi telah dilaksanakan sejak tahun 2016, akan tetapi belum dilakukan evaluasi lebih lanjut pada standar proses pembelajaran sehingga belum terlihat capaian pembelajaran yang dihasilkan.Tujuan penelitian ini adalah untuk memperoleh informasi pelaksanaan standar proses pembelajaran KKNI berdasarkan model evaluasi CIPP (Context, Input, Process, Product), hambatan, dan tindak lanjut yang harus dilakukan dalam upaya meningkatkan dan perbaikan kualitas pembelajaran KKNI. Metode yang digunakan dalam penelitian ini adalah metode deskriptif kualitatif, dengan subjek penelitiannya mahasiswa dan dosen. Hasil penelitian menunjukkan komponen evaluasi context pada aspek kondisi lingkungan belajar dan karakteristik proses pembelajaran pada kategori sangat baik. Komponen evaluasi input menunjukkan aspek perencanaan proses pembelajaran dan sarana prasarana pada kategori sangat baik. Komponen evaluasi process menunjukkan aspek pelaksanaan proses pembelajaran pada kategori sangat baik, dan komponen evaluasi product menunjukkan pada prestasi akademik mahasiswa pada kategori baik. Dengan demikian, pelaksanaan standar pembelajaran KKNI Program Studi Pendidikan Geografi dapat terlaksana dengan baik. Adapun hambatan dalam pelaksanaan standar proses pembelajaran KKNI ini adalah sulitnya melakukan penyesuaian kurikulum lama dan baru dan kebingungan mahasiswa terhadap perubahan kurikulum. Tindak lanjutnya yaitu program studi lebih meningkatkan kualitas standar proses pembelajaran agar tujuan pembelajaran lulusan dapat tercapai.
\end{abstract}

Kata Kunci : Evaluasi Model CIPP, KKNI, Standar Proses Pembelajaran

\section{PENDAHULUAN}

Peraturan Presiden nomor 8 tahun 2012 yang dimaksud Kerangka Kualifikasi Nasional Indonesia (KKNI) adalah kerangka penjenjangan kualifikasi kompetensi yang menyandingkan, menyetarakan, dan mengintegrasikan antara bidang pendidikan dan bidang pelatihan kerja serta pengalaman kerja dalam rangka pemberian pengakuan kompetensi kerja sesuai dengan struktur pekerjaan di berbagai sektor. Penyetaraan yang dimaksud adalah proses penyandingan dan pengintegrasian capaian pembelajaran yang diperoleh melalui pendidikan, pelatihan kerja, dan pengalaman kerja. Sedangkan yang dimaksud capaian pembelajaran adalah kemampuan yang 
diperoleh melalui internalisasi pengetahuan, sikap, keterampilan, kompetensi, dan akumulasi pengalaman kerja. Berdasarkan hal tersebut, KKNI terdiri atas 9 (sembilan) jenjang kualifikasi, dimulai dari jenjang 1 (satu) sebagai jenjang terendah sampai dengan jenjang 9 (sembilan) sebagai jenjang tertinggi. Setiap jenjang kualifikasi pada KKNI memiliki kesetaraan dengan capaian pembelajaran yang dihasilkan melalui pendidikan, pelatihan kerja atau pengalaman kerja yang dinyatakan dalam bentuk keterangan yang dikeluarkan oleh tempat yang bersangkutan bekerja.

Permenristekdikti Nomor 44 tahun 2015 tentang Standar Nasional Pendidikan Tinggi pasal 3, salah satu tujuannya adalah untuk menjamin tercapainya tujuan pendidikan tinggi yang berperan strategis dalam mencerdasakan kehidupan bangsa, memajukan ilmu pengetahuan dan teknologi dengan menerapkan nilai humaniora serta pembudayaan dan pemberdayaan bangsa Indonesia yang berkelanjutan. Selain itu, untuk mencapai standar nasional diperlukan pemenuhan 8 (delapan) standar pendidikan, yaitu standar kompetensi lulusan, standar isi, standar proses, standar penilaian pembelajaran, standar dosen dan tenaga kependidikan, standar sarana dan prasarana pembelajaran, standar pengelolaan pembelajaran, dan standar pembiayaan pembelajaran. Oleh karena itu, Program Studi Pendidikan Geografi sebagai salah satu dari program studi yang ada di Jurusan IPS, menyelenggarakan pendidikan dengan tujuan menghasilkan sarjana pendidikan Geografi yang memiliki wawasan, pengetahuan, keterampilan, nilai dan sikap dasar berkualitas menuju keprofesionalan dalam bidang pendidikan Geografi.

Pelaksanaan kurikulum KKNI di Program Studi Pendidikan Geografi telah dilaksanakan sejak tahun 2016, akan tetapi belum dilakukannya evaluasi lebih lanjut pada standar proses pembelajaran sehingga belum terlihat capaian pembelajaran yang dihasilkan. Selain itu, peneliti belum melihat perbedaan penerapan proses pembelajaran dari kurikulum sebelumnya, baik dari prosesnya maupun capaian pembelajaran lulusan yang dihasilkan. Oleh karena itu, untuk memaksimalkan pelaksaan kurikulum KKNI, peneliti mengkaji lebih mendalam pelaksanaan standar proses pembelajaran KKNI di Program Studi Pendidikan Geografi Universitas PGRI Palembang berdasarkan pada model evaluasi CIPP (Context, Input, Process, Product), hambatan yang dihadapi Program Studi Pendidikan Geografi, dan tindak lanjut yang harus dilakukan dalam upaya meningkatkan perbaikan kualitas pembelajaran KKNI.

Untuk melaksanakan tuntutan KKNI di perguruan tinggi dan capaian pembelajaran lulusan diperlukan evaluasi pencapaian pembelajaran salah satunya melalui standar proses pembelajaran. Hal tersebut didasarkan pada fungsi evaluasi yang merupakan salah satu rangkaian kegiatan dalam meningkatkan kualitas pembelajaran. lebih lanjut, Stufflebeam dan Shinkfield dalam Mardapi (2012) mengemukakan bahwa:

"Evaluation is the process of delineating, obtaining and providing descriptive and judgment information about the worth and merit of some object's goals, design, implementation, and impact in order to guide decision making, serve needs for accountability, and promote nderstanding of the involved phenomena."

Evaluasi sebagai suatu proses menyediakan informasi yang dapat dijadikan sebagai pertimbangan untuk menentukan tujuan yang dicapai, desain, implementasi dan dampak untuk membuat keputusan, pertanggungjawaban, dan meningkatkan pemahaman, sehingga evaluasi diartikan sebagai bahan pertimbangan dalam pengambilan keputusan (Eko, 2009:3).

Melalui evaluasi pelaksanaan standar proses pembelajaran KKNI di Program Studi Pendidikan Geografi ini diharapkan dapat memperoleh informasi dan data yang dapat dijadikan bahan evaluasi agar capaian pembelajaran lulusan dapat terlaksana dengan baik dan efektif.

Undang-Undang nomor 12 tahun 2012 tentang Pendidikan Tinggi pasal 5 menjelaskan, 
yaitu; (1) berkembangknya potesi mahasiswa agar menjadi manusia yang beriman dan bertaqwa kepada Tuhan Yang Maha Esa dan berakhlak mulia, serta berilmu, cakap, kreatif, mandiri, terampil, kompeten, dan berbudaya untuk kepentingan bangsa; (2) dihasilkannya lulusan yang menguasai cabang ilmu/ pengetahuan dan atau teknologi untuk memenuhi kepentingan nasional dan peningkatan daya saing bangsa; (3) dihasilkannya ilmu pengetahuan dan teknologi melalui penelitian yang memperhatikan dan menerapkan nilai humaniora agar bermanfaat bagi kemajuan bangsa, serta kemajuan peradaban dan kesejahteraan umat manusia; (4) terwujudnya pengabdian kepada masyarakat berbasis penalaran dan karya penelitian yang bermanfaat dalam memajukan kesejahteraan umum dan mencerdaskan kehidupan bangsa. Berdasarkan fungsi dan tujuan tersebut perguruan tinggi sebagai penyelenggara pendidikan tinggi mempunyai tanggung jawab besar dalam pelaksanaannya, sehingga kemajuan pendidikan di Indonesia dapat semakin baik dan berkualitas.

Kurikulum adalah seperangkat rencana dan pengaturan mengenai capaian pembelajaran lulusan, bahan kajian, proses, dan penilaian yang digunakan sebagai pedoman penyelenggaraan program studi. Saat ini pemerintah telah memberlakukan kurikulum terbaru untuk perguruan tinggi yang disebut dengan Kerangka Kualifikasi Nasional Indonesia yang selanjutnya disingkat KKNI. Kurikulum KKNI adalah kerangka penjenjangan kualifikasi kompetensi yang dapat menyandingkan, menyetarakan, dan mengintegrasikan antara bidang pendidikan dan bidang pelatihan kerja serta pengalaman kerja dalam rangka pemberian pengakuan kompetensi kerja sesuai dengan struktur pekerjaan di berbagai sektor. Kurikulum KKNI penting dilaksanakan karena merupakan perwujudan mutu dan jati diri bangsa Indonesia terkait dengan sistem pendidikan dan pelatihan nasional yang dimiliki Indonesia. Selain itu, penerapan KKNI di perguruan tinggi akan menguatkan akuntabilitas penyelenggaraan pendidikan sekaligus menjamin kualitas lulusan.
Pelaksanaan KKNI melibatkan semua aspek salah satunya peran program studi. Program Studi adalah kesatuan kegiatan pendidikan dan pembelajaran yang memiliki kurikulum dan metode pembelajaran tertentu dalam satu jenis pendidikan akademik, pendidikan profesi, dan/atau pendidikan vokasi. Dengan demikian, adanya target pencapaian ini, perguruan tinggi harus mampu menjabarkan capaian pembelajaran pada setiap mata kuliah yang ada sehingga tersusun sesuai kebutuhan profil lulusan.

Pembelajaran adalah proses interaksi mahasiswa dengan dosen dan sumber belajar pada suatu lingkungan belajar. Dalam melaksanakan proses pembelajaran terdapat standar proses pembelajaran yang telah ditetapkan oleh standar nasional pendidkikan tinggi. Menurut Permenristekdikti Nomor 44 tahun 2015 menyebutkan bahwa standar proses pembelajaran merupakan kriteria minimal tentang pelaksanaan pembelajaran pada program studi untuk memperoleh capaian pembelajaran lulusan. Standar proses sebagaimana dimaksud mencakup;(a) karakteristik proses pembelajaran; (b) perencanaan proses pembelajaran ; (c) pelaksanaan proses pembelajaran; dan (d) beban belajar mahasiswa.

Karakteristik proses pembelajaran sebagaimana dimaksud dalam pasal 10 ayat (2) huruf a terdiri atas sifat interaktif, holistik, integratif, saintifik, kontekstual, tematik, efektif, kolaboratif, dan berpusat pada mahasiswa. Adapun yang dimaksud dari sifat-sifat tersebut sebagai berkut.

1) Interaktif adalah capaian pembelajaran lulusan diraih dengan mengutamakan proses interaksi dua arah antara mahasiswa dan dosen.

2) Holistik adalah proses pembelajaran mendorong terbentuknya pola pikir yang komprehensif dan luas dengan menginternalisasi keunggulan dan kearifan lokal maupun nasional.

3) Integratif adalah capaian pembelajaran lulusan diraih melalui proses pembelajaran yang 
terintegrasi untuk memenuhi capaian pembelajaran lulusan secara keseluruhan dalam satu kesatuan program melalui pendekatan antardisiplin dan multidisiplin.

4) Saintifik adalah capaian pembelajaran lulusan diraih melalui proses pembelajaran yang mengutamakan pendekatan ilmiah sehingga tercipta lingkungan akademik yang berdasarkan sistem nilai, norma, dan kaidah ilmu pengetahuan serta menjunjung tinggi nilai-nilai agama dan kebangsaan.

5) Kontekstual adalah capaian pembelajaran lulusan diraih melalui proses pembelajaran yang disesuaikan dengan tuntutan kemampuan menyelesaikan masalah dalam ranah keahliannya.

6) Tematik adalah capaian pembelajaran lulusan diraih melalui proses pembelajaran yang disesuaikan dengan karakteristik keilmuan program studi dan dikaitkan dengan permasalahan nyata melalui pendekatan transdisiplin.

7) Efektif adalah capaian pembelajaran lulusan diraih secara berhasil guna dengan mementingkan internalisasi materi secara baik dan benar dalam kurun waktu yang optimum.

8) Kolaboratif adalah capaian pembelajaran lulusan diraih melalui proses pembelajaran bersama yang melibatkan interaksi antar individu pembelajar untuk menghasilkan kapitalisasi sikap, pengetahuan, dan keterampilan.

9) Berpusat pada mahasiswa adalah capaian pembelajaran lulusan diraih melalui proses pembelajaran yang mengutamakan pengembangan kreativitas, kapasitas, kepribadian, dan kebutuhan mahasiswa, serta mengembangkan kemandirian dalam mencari dan menemukan pengetahuan.

Acuan dari standar proses pembelajaran adalah standar kompetensi lulusan. Adapun yang dimaksud standar kompetensi lulusan adalah kriteria minimal tentang kualifikasi kemampuan lulusan yang mencakup sikap, pengetahuan, dan keterampilan yang dinyatakan dalam rumusan capaian pembelajaran lulusan. Rumusan capaian pembelajaran lulusan sebagaimana dimaksud pada ayat (1) wajib; (a) mengacu pada deskripsi capaian pembelajaran lulusan KKNI; dan (b) memiliki kesetaraan dengan jenjang kualifikasi pada KKNI.

Perencaaan proses pembelajaran disusun untuk setiap mata kuliah dan disajikan dalam recana pembelajaran semester (RPS) atau istilah lain yang ditetapkan dan dikembangkan oleh dosen secara mandiri atau bersama dalam kelompok keahlian suatu bidang ilmu pengetahuan dan/atau teknologi dalam program studi. RPS atau sitilah lain paling sedikit memuat sebagai berikut.

a. nama program studi, nama dan kode mata kulia, semester, sks, nama dosen pengampu;

b. capaian pembelajaran lulusan yang dibebankan pada mata kuliah

c. kemampuan akhir yang direncanakan pada tiap tahap pembelajaran untuk memenuhi capaian pembelajaran lulusan;

d. bahan kajian yang terkait dengan kemampuan yang akan dicapai;

e. metode pembelajaran;

f. waktu yang disediakan untuk mencapai kemampuan pada tiap tahap pembelajaran;

g. pengalaman belajar mahasiswa yang diwujudkan dalam deskripsi tugas yang harus dikerjakan oleh mahasiswa selama satu semester;

h. kriteria, indikator, dan bobot penilaia; dan

i. daftar referensi yang digunakan.

Pelaksanaan proses pembelajaran berlangsung dalam bentuk interaksi antara dosen mahasiswa, dan sumber belajar dalam lingkungan belajar tertentu, dilaksanakan sesuai RPS atau istilah lain, dilakukan secara sistematis dan terstruktur melalui berbagai mata kuliah dan beban belajar yang terukur. Selain itu, wajib menggunakan metode pembelajaran yang efektif sesuai dengan 
karakteristik mata kuliah untuk mencapai kemampuan tertentu yang ditetapkan dalam mata kuliah dalam rangkaian pemenuhan capaian pembelajaran lulusan (CPL).

Metode pembelajaran dapat dipilih berdasarkan mata kuliah. Adapun metode yang dapat digunakan, yaitu diskusi kelompok, simulasi, studi kasus, pembelajaran kolaboratif, pembelaaran kooperatif, pembelajaran berbasisi proyek, pembelajaran berbasis masalah, atau metode pembelajaran lain yang dapat secara efektif memfasilitasi pemenuhan capaian pembelajaran lulusan. Setiap mata kuliah dapat megunakan satu atau gabungan dari beberapa metode pembelajaran dan diwadahi dalam suatu bentuk pembelajaran. Bentuk pembelajaran yang dimaksud, yaitu kuliah, responsi dan tutorial, seminar, dan praktikum, praktik studio, praktik bengkel, atau praktik lapangan.

Berdasarkan Permendikbud No. 49/2014 tentang Standar Nasional Pendidikan Tinggi, beban belajar mahasiswa dinyatakan dalam besaran satuan kredit semester (SKS). Semester merupakan satuan waktu kegiatan pembelajaran efektif selama paling sedikit 16 (enam belas) minggu termasuk ujian tengah semester dan ujian akhir semester. Satu tahun akademik terdiri atas dua semester dan perguruan tinggi dapat menyelenggarakan semester antara. Semester antara diselenggarakan selama paling sedikit 8 (delapan) minggu, beban belajar mahasiswa paling banyak 9 (sembilan) sks sesuai beban belajar mahasiswa untuk memenuhi capaian pembelajaran yang telah ditetapkan.

Beban belajar mahasiswa program diploma II, program diploma III, program diploma IV/sarjana terapan dan program sarjana yang berprestasi akademik tinggi (IPS > 3,00 dan memenuhi etika akademik), setelah 2 (dua) semester pada tahun akademik yang pertama dapat mengambil maksimum 24 sks pada semester berikutnya

Evaluasi adalah proses penerapan yang dilakukan untuk mengumpulkan dan mensistensiskan pembuktian sebagai kesimpulan tentang kualitas program, produk, orang, kebijakan, proposal, atau perencanaan. Pengertian tersebut menunjukkan bahwa evaluasi tidak hanya membahas tentang pendidikan akan tetapi dapat mengkaji seluruh aspek. Evaluasi merupakan suatu proses atau kegiatan pemilihan, pengumpulan, analisis dan penyajian yang dapat digunakan sebagai dasar pengambilan keputusan serta penyusunan program selanjutnya. Untuk melaksanakan program yang sesuai ketentuan, maka perlu diketahui tujuan dari evaluasi.

Adapun tujuan evaluasi yaitu untuk mengukur dampak program terhadap tujuan dalam membuat keputusan dan perbaikan program. Dengan demikian, evaluasi merupakan proses yang sistematis dan berkelanjutan untuk mengumpulkan, mendeskripsikan, menginterpretasikan dan menyajikan informasi yang dapat digunakan sebagai dasar membuat keputusan, menyusun kebijakan maupun menyusun program selanjutnya, atau dapat diartikan sebagai upaya untuk memperoleh informasi yang akurat dan objektif tentang suatu program. Informasi dapat berupa proses pelaksanaan program, dampak atau hasil yang dicapai, dan efesiensi pemanfaatan hasil evaluasi terhadap suatu program.Untuk menghasilkan tujuan evaluasi seperti yang diharapkan diperlukan standar. Adapun standar dalam melakukan evaluasi dijelaskan oleh Mertens (2010) sebagai berikut.

"The standars are organized according to five main attributes of evaluations: (a) feasibility-the extent to which the evaluation can be implemented successfully in a specific setting; (b) propriety-how human, ethical, moral, proper, legal, and professional an evaluation is; (c) accuracy-how dependable, precise, truthful, and trustworthy an evaluation is; (d) utility-how useful and appropriately used an evaluation is; (e) meta-evaluation-the extent to which the quality of the evaluation itself is assured and controlled".

Kelima standar memiliki hubungan satu sama lain, yaitu feasibility yang berhubungan dengan 
standar pelaksanaan evaluasi, propriety yaitu berhubungan dengan etika, moral, dan profesionalitas, accuracy yaitu adanya kejujuran atau bukti yang akurat dalam melaksanakan evaluasi, utility, manfaat yang diperoleh dari evaluasi, dan meta-evaluation kualitas evaluasi dan adanya pengawasan yang baik. Dalam penelitian ini model yang digunakan adalah model evaluasi CIPP. Model evaluasi CIPP dalam pelaksanan lebih banyak digunakan diakarenakan lebih komprehensif dibanding model evaluasi lainnya. CIPP merupakan singkatan dari context, input, process, and product. Tujuannya adalah untuk membantu administrator di dalam membuat keputusan. Model ini membagi empat jenis kegiatan evaluasi, yaitu (a) context evaluation to serve planning decision, yaitu konteks evaluasi untuk membantu administrator merencanakan keputusan, menentukan kebutuhan program, dan merumuskan tujuan program. (b) Input evaluation, structuring decision. Kegiatan evaluasi bertujuan untuk membantu mengatur keputusan, menentukan sumber-sumber, alternative apa yang akan diambil, apa rencana dan strategi untuk mencapai kebutuhan, dan bagaimana prosedur kerja untuk mencapainya. (c) Process evaluation, to serve implementing decision. Kegiatan evaluasi ini bertujuan untuk membantu melaksanakan keputusan. pertanyaan yang harus dijawab adalah bagaimana suatu rencana telah dilaksanakan, apakah rencana tersebut sesuai dengan prosedur kerja, dan apa yang harus diperbaiki. (d) Product evaluation, to serve recycling decision. Kegiatan evaluasi ini bertujuan untuk membantu keputusan selanjutnya.

Program Studi pendidikan Geografi adalah salah satu dari dua program Studi yang ada di Jurusan Ilmu Pendidikan. Program studi ini menyelenggarakan pendidikan dengan tujuan menghasilkan sarjana pendidikan Geografi yang memiliki wawasan, pengetahuan, keterampilan, nilai dan sikap dasar berkualitas menuju keprofesionalan dalam bidang pendidikan Geografi. Visi program studi pendidikan Geografi adalah pada tahun 2025, Program studi pendidikan
Geografi menjadi lembaga yang mampu menghasilkan lulusan pendidikan Geografi yang unggul, professional, berdaya saing, serta berperan aktif dalam pembangunan nasional. Sedangkan misi program studi pendidikan Geografi, yaitu; (1) menyelenggarakan kegiatan pendidikan dan pengajaran dalam bidang Geografi yang sesuai dengan spesialisasi disiplin ilmu yang dimiliki. (2) meningkatkan kualitas dan kuantitas penelitian dan pengabdian kepada masyarakat dalam bidang Pendidikan Geografi secara berkelanjutan. (3) mengembangkan dan menerapkan ilmu pengetahuan dan teknologi di bidang Pendidikan Geografi. (4) meningkatkan kerjasama dengan instansi lain (instansi pemerintahan, perguruan tinggi, sekolah, dan stakeholder di tingkat daerah, nasional dan internasional secara berkelanjutan).

Adapun tujuan program studi pendidikan Geografi, yaitu; (1) menghasilkan lulusan tenaga kependidikan Geografi yang memiliki kompetensi pada bidang pendidikan dasar dan menengah. (2) menghasilkan lulusan yang mampu melaksanakan penelitian dalam bidang Pendidikan Geografi. (3) menghasilkan lulusan yang mampu melaksanakan pengabdian kepada masyarakat dalam bidang pendidikan Geografi. (4) menghasilkan tenaga enterpreneurship yang handal di bidang Pendidikan Geografi dan siap untuk mengikuti perkembangan zaman. (5) menghasilkan lulusan yang dapat mengakses teknologi informasi dan diharapkan dapat menciptakan lapangan pekerjaan dalam bidang Pendidikan Geografi yang sesuai dengan kebutuhan masyarakat. (6) menghasilkan lulusan tenaga kependidikan Geografi yang memiliki daya saing tinggi, kreatif, dan inovatif. (7) menjalin kerjasama dengan instansi lain dalam meningkatkan kualitas pendidikan Geografi.

\section{METODOLOGI PENELITIAN}

Penelitian ini menggunakan jenis penelitian evaluasi dengan metode deskriptif kualitatif. Penelitian kualitatif bertujuan untuk memahami obyek yang diteliti secara mendalam (Gunawan, 2015), sedangkan deskriptif digunakan untuk mendeskripsikan hasil temuan berdasarkan pada 
instrument yang digunakan. Oleh karena itu, peneliti akan menjelaskan secara deskriptif mengenai evaluasi pelaksanaan standar proses pembelajaran KKNI di Program Studi Pendidikan Geografi Universitas PGRI Palembang.

Model evaluasi yang digunakan dalam penelitian ini adalah model evaluasi CIPP (Context, Input, Proses, dan Product). Model ini digunakan untuk mengetahui pelaksanaan standar proses pembelajaran KKNI di Program Studi Pendidikan Geografi Universitas PGRI Palembang.

Sumber data dalam penelitian ini terdiri dari sumber primer dan sumber sekunder. Sumber data diambil secara purposive sampling. Teknik sampling ini digunakan karena peneliti mengambil informan yang sesuai dan relevan dengan permasalahan penelitian.

Jenis data yang digunakan dalam penelitian ini adalah data primer dan data sekunder. Data primer adalah data yang langsung diperoleh dari sumber data pertama, dalam hal ini yang dimaksud data primer adalah hasil wawancara yang mendalam di lapangan dan hasil instrumen angket. Data tersebut berupa hasil catatan wawancara dan hasil angket. Sedangkan data sekunder adalah data yang diperoleh dari sumber kedua atau sumber sekunder dari data yang dibutuhkan. Data sekunder yang diperoleh dalam penelitian ini diperoleh dari studi pustaka dan dokumen-dokumen yang berhubungan dengan data penelitian.

Pengumpulan data pada penelitian ini menggunakan teknik angket/angket, wawancara, observasi, dan dokumentasi. Menurut Milles dan Huberman dalam (Ridvia Lisa, 2010) analisis terdiri dari tiga alur kegiatan yang terjadi secara bersamaan, yaitu reduksi data, penyajian data, dan penarikan kesimpulan/verifikasi. Ketiga alur tersebut menjadi gambaran keberhasilan secara berurutan sebagai rangkaian kegiatan analisis yang saling susul menyusul.

\section{HASIL DAN PEMBAHASAN}

Berdasarkan hasil penelitian yang meliputi Hasil kuesioner mahasiswa menunjukkan bahwa komponen evaluasi context pada aspek kondisi lingkungan belajar dan karakteristik proses pembelajaran pada kategori sangat baik. Lingkungan belajar nyaman dan tenang, ruang kelas jauh dari kebisingan, suasana ruang kelas selalu bersih dan menyenangkan.Adapun hasil evaluasi komponen context dapat dilihat pada gambar 1 di bawah ini.

\section{Hasil Komponen Evaluasi Context}

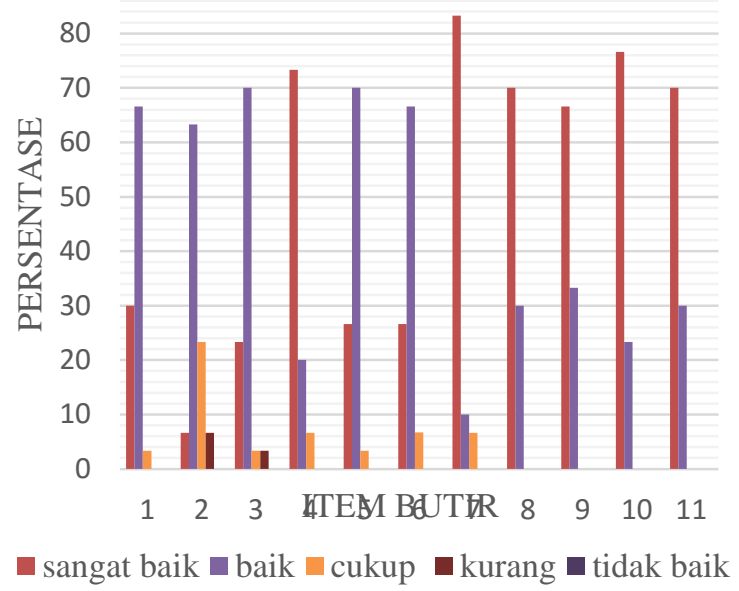

Gambar 1. Hasil Komponen Evaluasi Context (Sumber: pengolahan data 2019)

Komponen evaluasi input pada aspek perencanaan proses pembelajaran dan sarana prasarana pada pada kategori sangat baik. Dosen menyampaikan silabus perkuliahan, dosen menyampaikan kontrak perkuliahan, dosen menyiapkan bahan ajar dan sumber belajar lainnya. Tersedianya sarana dan prasarana yang memadai pendukung proses pembelajaran, tersedianya laboratorium yang sesuai dengan kebutuhan mahasiswa sebagai tempat praktikum yang mendukung proses pembelajaran, tersedianya perpustakaan yang lengkap sebagai sumber informasi bagi mahasiswa.Gambar 2 di bawah ini menunjukkan hasil komponen evaluasi input. 
Hasil Komponen Evaluasi

Jurnal Swarnabhumi Vol. 4, No.2, Agustus 2019

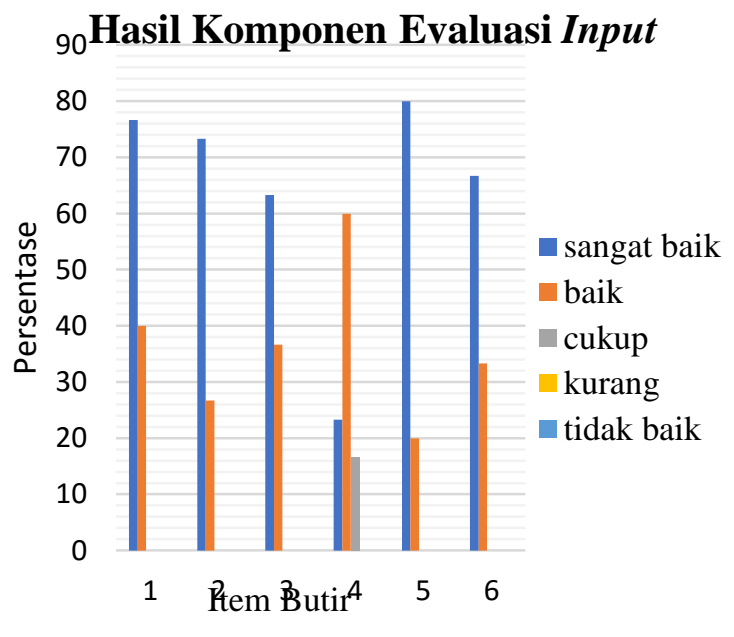

Gambar 2. Hasil Komponen Evaluasi Input

(Sumber: pengolahan data 2019)

Komponen evaluasi process pada aspek pelaksanaan proses pembelajaran pada kategori sangat baik. Pelaksanaan proses pembelajaran disesuaikan dengan kurikulum KKNI, materi disampaikan secara menarik sehingga menumbuhkan minat dan semangat pada diri mahasiswa dalam mengikuti proses pembelajaran, pelaksanaan pembelajaran dilaksanakan secara sistematis dan terukur (kegiatan awal, inti, dan penutup), menggunakan media pembelajaran yang mendukung ketercapaian materi pembelajaran, menggunakan metode/strategi pembelajaran yang efektif sesuai karakteristik mata kuliah, pelaksanaan proses pembelajaran dosen melaksanakan salah satu bentuk pembelajaran (kuliah, responsi dan tutorial, seminar, dan praktikum), melakukan evaluasi proses pembelajaran untuk mengukur ketercapaian materi sesuai tujuan yang ditetapkan. Hasil komponen process ini senada dengan hasil penelitian Fatmawati (2016) yang menunjukkan bahwa pelaksanaan pembelajaran di Prodi DKV MSD berada pada kategori baik dengan nilai 3,20. Hasil komponen evaluasi process dapat dilihat pada gambar 3 berikut ini:

\section{Gambar 3.}

Hasil

Komponen

Evalausi

Process

(Sumber:

pengolahan

data 2019) Process

80

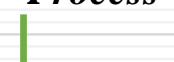

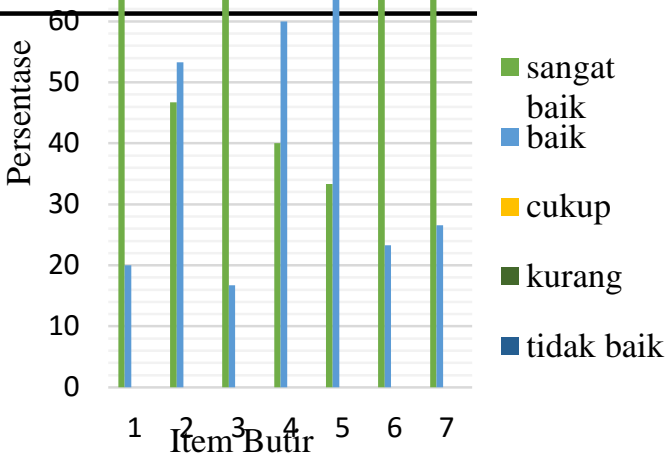

Kompo

nen evaluasi

product aspek prestasi akademik mahasiswa pada kategori baik. Perkuliahan efektif paling sedikit 16 pertemuan termasuk UTS dan UAS, hasil belajar yang diperoleh dengan hasil sangat baik, prestasi akademik tinggi diatas 3.00, setelah 2 semester pada tahun akademik pertama dapat mengambil 24 SKS pada semester berikutnya. Dengan demikian, hasil evaluasi context, input, process, dan product pada kuesioner mahasiswa menujukkan bahwa kesiapan program studi dalam pelaksanaan kurikulum KKNI pada kategori sangat baik. Hal tersebut terlihat dari masing-masing komponen yang menghasilkan penilaian dengan kategori sangat baik. Hasil komponen evaluasi product dapat dilihat pada gambar 4 di bawah ini:

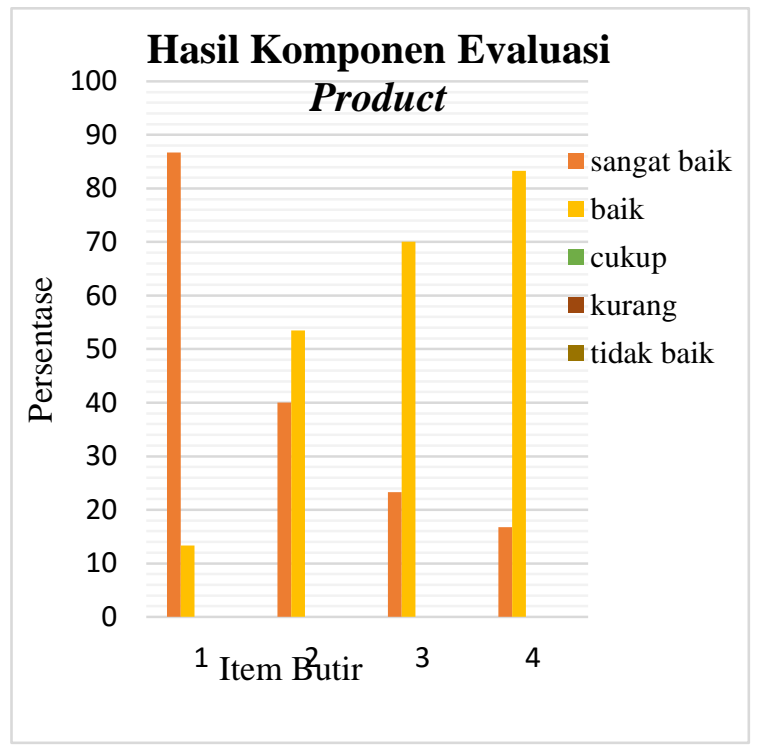

Gambar 4. Hasil Komponen Evaluasi Product (Sumber: pengolahan data 2019)

Hasil wawancara dengan ketua program studi menunjukkan bahwa ditemukannya hambatan dalam pelaksanaan kurikulum KKNI, yaitu 
melakukan penyesuaian kurikulum lama dan baru, kesiapan sumber daya manusia yang berpengaruh terhadap penerapan dilapangan sehingga diperlukan manajemen yang baik. Program Studi Pendidikan Geografi dalam pelaksanaan kurikulum KKNI telah berusaha untuk memperbaiki dan menerapkan kurikulum KKNI dengan berbagai kendala, namun melalui kerja keras dan keterlibatan semua pihak akhirnya program studi dapat menerapkan kurikulum KKNI meskipun dengan berbagai kekurangan yang ada. Langkahlangkah yang dilakukan Program Studi yaitu melakukan perbaikan kurikulum, memperbaiki visi dan misi, capaian pembelajaran, profil lulusan, sturktur kurikulum, penyesuaian SKS pada mata kuliah tertentu, melakukan sosialisasi terkait dengan perubahan kurikulum, dan melibatkan semua pihak untuk berpartisipasi dalam menciptkan lingkungan akademis yang kreatif, inovatif, dan berkualitas. Selain dari informasi yang diperoleh dari Kaprodi, peneliti juga melakukan wawancara dengan Ka.Lab yang memiliki tanggung jawab dalam pelaksanaan proses pembelajaran praktikum. Karena pada dasarnya kedua proses pembelajaran tersebut tidak dapat terpisahkan satu dengan yang lain. Pelaksanaan perkuliahan sangat perlu diperhatikan apalagi yang berhubungan dengan praktik, mulai dari kesiapan materi, modul, dan alat yang digunakan dalam praktikum. Sarana yang ada sangat mendukung pelaksanaan proses pembelajaran praktikum di laboratorium sehingga mahasiswa merasa senang dan nyaman.

Berdasarkan temuan-temuan yang ada, baik dari kuesioner, wawancara, dan observasi, menunjukkan bahwa evaluasi pelaksanaan standar proses pembelajaran KKNI di Program Studi Pendidikan Geografi dapat terlaksana dengan baik, meskipun masih perlu dilakukan perbaikan dalam upaya meningkatkan kualitas lulusan. Selain itu, adapun hambatan-hambatan yang ditemukan pada pelaksanaan kurikulum KKNI adalah sulitnya melakukan penyesuaian kurikulum lama dan baru, kebingungan mahasiswa karena perubahan kurikulum sehingga mahasiswa yang telah habis masa berlakunya kurikulum sebelumnya (lama) harus menyesuaikan mata kuliah dengan kurikulum terbaru KKNI.

Adapun tindak lanjut yang harus dilakukan oleh Program Studi Pendidikan Geografi, yaitu: (a) komponen evaluasi context, Program Studi harus lebih meningkatkan karakteristik proses pembelajaran, yang lebih integrative, saintifik, efektif, kolaboratif dan berpusat pada mahasiswa. Hal tersebut dimaksudkan agar dalam pelaksanaannya dosen lebih memperhatikan kebutuhan mahasiswa dan capaian pembelajaran yang dihasilkan. Lebih maksimal dalam melakukan sosialisasi terhadap perubahan kurikulum, meningkatkan kualitas sumber daya manusia (dosen) agar lebih kreatif dalam mendesain proses pembelajaran sehingga interaksi antara dosen dan mahasiswa dapat terjalin dengan baik. (b) komponen evaluasiinput, dosen dalam mempersiapkan perangkat pembelajaran harus dilakukan dengan lebih baik dan disesuaikan dengan ketentuan yang berlaku, meningkatkan kualitas bahan ajar, buku ajar, modul yang dibuat sendiri oleh dosen, dan meningkatkan sarana dan prasarana yang mendukung proses pembelajaran. (c) komponen evaluasi process, meningkatkan interaksi antara dosen, mahasiswa, dan sumber belajar, dilaksanakan sesuai RPS, dilakukan secara sistematis dan terukur melalui berbagai mata kuliah dan beban belajar yang terukur, menggunakan metode pembelajaran yang efektif dan bentuk pembelajaran yang bervariasi sesuai dengan karakteristik mata kuliah untuk mencapai kemampuan yang ditetapkan dalam mata kuliah untuk pemenuhan capaian pembelajaran lulusan (CPL). (d) komponen evaluasi product, perlunya meningkatkan prestasi akademik mahasiswa melalui produk pembelajaran yang dihasilkan dari proses pembelajaran. Hal ini dimaksudkan agar mahasiswa dapat mengembangkan kreativitas melalui karya baik tertulis maupun bentuk lainnya. Penerapan kurikulum KKNI di perguruan tinggi sangatlah dibutuhkan karena dapat meingkatkan potensi mahasiswa agar memiliki wawasan luas 
dan soft skills yang sesuai dengan kriteria yang dibutuhkan masyarakat.

Dengan demikian, evaluasi pelaksanaan standar proses pembelajaran kurikulum KKNI Program Studi Pendidikan Geografi terlaksana dengan baik, hal tersebut sesuai dengan Permenristekdikti Nomor 44 tahun 2015 yang menjelaskan bahwa standar proses pembelajaran merupakan kriteria minimal tentang pelaksanaan pembelajaran pada program studi untuk memperoleh capaian pembelajaran lulusan, yang mencakup standar proses sebagaimana dimaksud mencakup; (a) karakteristik proses pembelajaran; (b) perencanaan proses pembelajaran; (c) pelaksanaan proses pembelajaran; dan (d) beban belajar mahasiswa.

\section{SIMPULAN}

Kesimpulan dalam penelitian ini sebagai berikut.

1) Adapun pelaksanaan standar proses pembelajaran KKNI Program Studi Pendidikan Geografi dengan model CIPP (context, input, process, product), yaitu komponen evaluasi context menunjukkan bahwa padaaspek kondisi lingkungan belajar dan karakteristik proses pembelajaran pada kategori sangat baik. Komponen evaluasi input menunjukkan bahwa pada aspek perencanaan proses pembelajaran dan sarana prasarana pada pada kategori sangat baik. Komponen evaluasi process menunjukkan bahwa pada aspek pelaksanaan proses pembelajaran pada kategori sangat baik, dan komponen evaluasi product menunjukkan bahwa pada prestasi akademik mahasiswa pada kategori baik. Dengan demikian, pelaksanaan standar proses pembelajaran KKNI Program Studi Pendidikan Geografi dapat terlaksana dengan baik,

2) Hambatan Program Studi Pendidikan Geografidalam pelaksanaan standar proses pembelajaran KKNI adalah sulitnya melakukan penyesuaian kurikulum lama dan baru, kebingungan mahasiswa karena perubahan kurikulum sehingga mahasiswa yang telah habis masa berlakunya kurikulum sebelumnya (lama) harus menyesuaikan mata kuliah dengan kurikulum terbaru KKNI.

3) Tindak lanjut dalam meningkatkan pelaksanaan standar proses pembelajaran KKNI adalah (a) komponen evaluasi context, program studi harus lebih meningkatkan karakteristik proses pembelajaran, yang lebih integrative, saintifik, efektif, kolaboratif dan berpusat pada mahasiswa. (b) komponen evaluasi input, mempersiapkan perangkat pembelajaran dengan lebih baik dan disesuaikan dengan ketentuan yang berlaku, meningkatkan kualitas bahan ajar, buku ajar, modul yang dibuat sendiri oleh dosen, dan meningkatkan sarana dan prasarana yang mendukung proses pembelajaran. (c) komponen evaluasi process, meningkatkan interaksi antara dosen, mahasiswa, dan sumber belajar, dilaksanakan sesuai RPS, dilakukan secara sistematis dan terukur melalui berbagai mata kuliah dan beban belajar yang terukur, menggunakan metode pembelajaran yang efektif dan bentuk pembelajaran yang bervariasi sesuai dengan karakteristik mata kuliah untuk mencapai kemampuan yang ditetapkan dalam mata kuliah untuk pemenuhan capaian pembelajaran lulusan (CPL). (d) komponen evaluasi product, perlunya meningkatkan prestasi akademik mahasiswa melalui produk pembelajaran yang dihasilkan dari proses pembelajaran. Hal ini dimaksudkan agar mahasiswa dapat mengembangkan kreativitas melalui karya baik tertulis maupun bentuk lainnya.

\section{DAFTAR PUSTAKA}

Fatmawati, Soraya, Ali Muhtadi. 2016. Evaluasi Pelaksanaan Pembelajaran Program Studi Desain Komunikasi Visual Msd Yogyakarta. Jurnal Inovasi Teknologi Pendidikan. Volume 3, No 1, hal.64-78

Gunawan, Imam. 2015. Metode Penelitian Kualitatif. Diakses 2 April 2018 http://fip.um.ac.id/wpcontent/uploads/2015/12 13 Metpen-Kualitatif.pdf 
Mardapi, D. 2012. Pengukuran Penilaian dan Evaluasi Pendidikan. Yogyakarta: Nuha Medika.

Mertens, Donna M. 2010. Research and Evaluation in Education and Psychology. Third Edition. SAGE.

Peraturan Presiden Republik Indonesia Nomor 8 tahun 2012 tentang Kerangka Kualifikasi Nasional Indonesia (KKNI). Presiden RI. Jakarta.

Peraturan Menteri Pendidikan Dan Kebudayaan Republik Indonesia Nomor 49 Tahun 2014 tentang Standar Nasional Pendidikan Tinggi.

Peraturan Menteri Riset, Teknologi, dan Pendidikan Tinggi Republik Indonesia Nomor 44 tahun 2015 tentang Standar Nasional Pendidikan Tinggi. Menteri Riset, Teknologi, dan Pendidikan Tinggi RI. Jakarta.
Putro Widoyoko, Eko. 2009. Evaluasi Program Pembelajaran : Panduan Praktis Bagi Pendidik dan Calon Pendidik. Yogyakarta : Pustaka Pelajar.

Ridvia Lisa, Maschandra, dan Rusman Iskandar. 2010. Analisis Data Kualitatif Model Miles dan Huberman. Program Magister Pendidikan Kejuruan Fakultas Teknik, Universitas Negeri Padang. https://www.academia.edu/7440214/ANALIS IS_PENELITIAN_KUALITATIF_MODEL_ MILES dan HUBERMAN. Diakses 22 September 2019.

Undang-undang Nomor 12 tahun 2012 tentang Pendidikan Tinggi. 